\title{
Editorial to the OCT Angiography in Glaucoma series
}

Optical coherence tomography angiography (OCT angiography) applied for glaucoma research and glaucoma patient management is one of the highest ranked and most rapidly developing area of ophthalmology. While OCT technology has been widely used in clinical practice for more than two decades OCT angiography reached clinical applicability only less than five years ago. It is now possible to objectively and reproducibly measure capillary perfusion in the retinal nerve fiber layer, the inner macular retina and the optic nerve head, all of which are essential in the glaucomatous structural damage and its progression. It has been shown that in these structures capillary perfusion is reduced in most forms of glaucoma, and in primary open-angle glaucoma (in which vascular dysregulation plays an important pathophysiological role) its measurable reduction precedes and predicts structural damage. Several important questions regarding OCT angiography, however, are under investigation. Therefore the review articles published in current series cover several essential and currently under investigation research areas. The reviews are important for all clinicians dealing with glaucoma patients, researchers working on any of the chronic progressive neurodegenerative diseases one of which is glaucoma, and those engineers, mathematicians and physicists whose research involves clinical aspects.

In the first paper Hollo reviews the research aspects and clinical applicability of the vessel density—visual field sensitivity relationship. The second review by Fard and Ritch provides detailed information on the role of OCT angiography in glaucoma detection and evaluation of glaucoma progression, and on the relationship of the various OCT angiography parameters to the spatially corresponding structural parameters. Finally, Tan et al. provide an extensive review on the different approaches of the quantification of the various OCT angiography metrics. This review is particularly important for all researchers, physicists and engineers working on ocular perfusion, ocular imaging and OCT angiography. As the Guest Editor of this series I am convinced that all readers with an interest in ophthalmology will usefully utilize the information summarized in the above reviews.

\section{Acknowledgments}

Funding: None.

\section{Footnote}

Provenance and Peer Review: This article was commissioned by the editorial office, Annals of Translational Medicine for the series "OCT Angiography in Glaucoma". The article did not undergo external peer review.

Conflicts of Interest: The author has completed the ICMJE uniform disclosure form (available at http://dx.doi.org/10.21037/ atm-2020-oct-04). The series "OCT Angiography in Glaucoma” was commissioned by the editorial office without any funding or sponsorship. GH served as the unpaid Guest Editor of the series and serves as an unpaid editorial board member of Annals of Translational Medicine from Dec 2019 to Nov 2021. The author has no other conflicts of interest to declare.

Ethical Statement: The author is accountable for all aspects of the work in ensuring that questions related to the accuracy or integrity of any part of the work are appropriately investigated and resolved.

Open Access Statement: This is an Open Access article distributed in accordance with the Creative Commons AttributionNonCommercial-NoDerivs 4.0 International License (CC BY-NC-ND 4.0), which permits the non-commercial replication and distribution of the article with the strict proviso that no changes or edits are made and the original work is properly cited (including links to both the formal publication through the relevant DOI and the license). See: https://creativecommons.org/licenses/by-nc$\mathrm{nd} / 4.0 /$. 


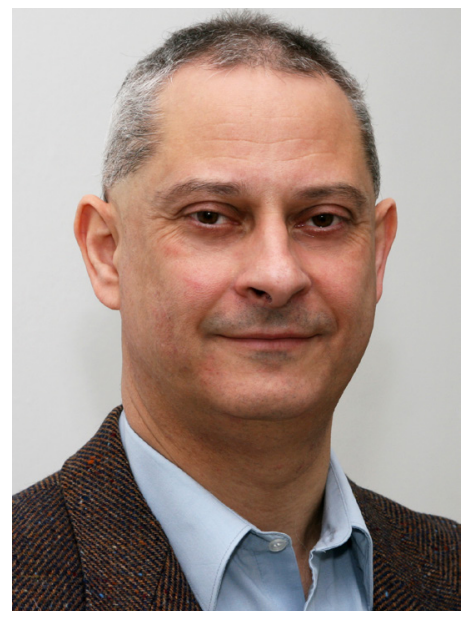

Gábor Holló

Gábor Holló, MD, PhD, DSc Department of Ophthalmology, Semmelweis University, Budapest, Hungary. (Email: hollo.gabor@med.semmelweis-univ.bu) Submitted Jul 22, 2020. Accepted for publication Jul 24, 2020. doi: $10.21037 / \mathrm{atm}-2020$-oct-04 View this article at: http://dx.doi.org/10.21037/atm-2020-oct-04

Cite this article as: Holló G. Editorial to the OCT Angiography in Glaucoma series. Ann Transl Med 2020;8(18):1202. doi: 10.21037/atm-2020-oct-04 